\title{
Textile azo dye decolorization and detoxification using bacteria isolated from textile effluents
}

\author{
ARUN KARNWAL \\ School of Bioengineering and Biosciences, Lovely Professional University, Phagwara, Punjab, India
}

\begin{abstract}
Azo dyes, which are highly toxic, carcinogenic, and mutagenic for living organisms, are used as coloring chemicals in textile industries. Physicochemical methods used for removing azo dyes are expensive, can generate secondary waste, and are not very efficient. In this study, we used a biological approach to reduce the toxicity of three azo dyes, i.e., congo red, methyl orange, and reactive red 198, from textile effluents. Six dye-decolorizing bacteria were screened from waste water obtained from the textile industry (in the dyeing process) at a concentration $100 \mathrm{mg} / \mathrm{l}$ for each azo dye. Using a 16S rRNA approach, the bacteria were identified and assigned as Enterococcus faecalis VTK04, Staphylococcus aureus VTK013, Pseudomonas aeruginosa VTK018, Proteus mirabilis VTK024, Bacillus cereus VTK035, and Enterococcus faecium VTK054. These bacteria were tested for their ability to produce biofilms on the abiotic surface. The adherence assay showed that VTK013, VTK054, and VTK024 had a potential to form stable biofilms on abiotic surfaces (OD570 = 1.37). Moreover, the dye decolorization potential was spectrophotometrically measured after seven days with and without a carbon substrate. The results demonstrated that the absence of the carbon source had a negative impact on decolorization, whereas a carbon-supplemented medium showed a considerable increase in the decolorization of congo red ( $80 \%$ and $96 \%$ by VTK013 and VTK018, respectively), methyl orange (100\% and 75\% by VTK054 and VTK035, respectively), and reactive red 198 ( $90 \%$ and $86 \%$ by VTK04 and VTK024, respectively). The phytotoxicity study of the treated dye solutions showed lesser toxicity compared to the untreated dye solution. These results support the possibility of using bacterial isolates for the biodegradation of azo dye effluents.
\end{abstract}

Key words: azo reactive dye, chick pea, decolorization, phytotoxic study, textile effluent, wheat

\section{Introduction}

Usually, artificial dyes are recalcitrant elements that form the primary constituents identified in particular effluents such as fabrics, papers, food, beauty products, and pharmaceutics industries (Jha et al., 2016). These types of coloring agents are polyaromatic molecules (Wang et al., 2018) that provide a permanent color to textile materials. Over 100,000 industrial synthetic chemical dyes of various classes have been generated globally, of which $60-70 \%$ belong to azo dyes, and their yearly production is $7 \times 10^{5}$ metric tons (Karim et al., 2018). Phytotoxicity investigations demonstrated that most fabric dyes are not hazardous; however, a small fraction of dye in the drinking water supply (5-60 mg/l) is clearly noticeable and has an impact on taste, odor, transparency, and gas mixability in water bodies (Karim et al., 2018; Neoh et al., 2015). However, their persistency and long-time exposure might lead to severe and undesirable outcomes such as mutagenic deterioration and carcinogenicity in living biota (Celebi et al., 2013; Mnif et al., 2016a; Vats and Mishra, 2017). For certain coloring operations, as much as $10-15 \%$ of the dyes used never affix to a fabric and are usually released in wastewater. The resulting colored refuse water generates a significant water toxicity issue/problem because of the color content and its hazardous components (Karim et al., 2018). Among all the synthetic chemical dyes, azo dyes contain a significant amount of synthetic organic colorants that are extensively applied (60-70\%) owing to the various types of colour tones they offer, lesser fa-

\footnotetext{
* Corresponding author: School of Bioengineering and Biosciences, Lovely Professional University, Jalandhar-Delhi G.T. Road, National Highway 1, Phagwara, Punjab 144411, India; e-mail: arunkarnwal@gmail.com
} 
ding, better binding with fabric material, and reduced energy usage (Chaieb et al., 2016). Azo dyes are organic compounds that contain a number of colouring azo functional groups (R1-N = N-R2) and aromatic rings, which were simply substituted by sulfonate groupings. These dyes are considered to be electron-deficient xenobiotic substances because they contain electron-withdrawing groups that produce electron insufficiency in the chemicals, which makes them resistant to degradation (Liu et al., 2013). However, because of water pollution-related legislation Water Act 1974 and Water Cess Act (1977-1988), several restraints are being placed on dye release in industrial wastewaters/effluents because of concerns related to environment and human health. Such legislations have forced industries to remove colouring chemicals from their effluents before they are released into water systems (Iqbal and Asgher, 2013). Several physicochemical methods, such as photocatalysis, ozonation, electrochemical oxidation process, adsorption via activated carbon, coagulation/flocculation, membrane filtration, and precipitation, are usually used for treating textile wastewater but these strategies are expensive and are producing considerable amount of sludge, which has to then be removed safely (Karim et al., 2018). Biological methods (such as microbial decolorization, microbial degradation, adsorption by (living or dead) microbial biomass, enzymatic degradation, and bioremediation) available for the biodegradation of dyes have been reported to yield better results compared to physicochemical methods. The biodegradation of dyes is effective and promising for the mineralization and detoxification of azo dyes. Note that biodegradation associated with azo dyes may take place either aerobically, anaerobically, or even by a combination of both methods. Previously, studies have reported the effectiveness of bacterial and fungi (such as Phanerochaete chrysosporium, Trametes (Coriolus) versicolor, Bjerkandera adusta, Aspergillus ochraceus, as well as species of Pleurotus and Phlebia, Irpex lacteus, Funalia trogii ATCC 200800, Aspergillus flavus, Alternaria solani, Lentinus polychrous, Pycnoporus sanguineus, Trametessp. SQ01, Chlorella pyrenoidosa, Chlorella vulgaris, and Oscillatoria tenuis, Micrococcus glutamicus NCIM 2168, EnterobacterEC3, Citrobactersp. CK3, and Pseudomonas aeruginosa) in the biodegradation of azo dyes (Ma et al., 2017; Paz et al., 2017). This study targeted the separation and recognition of microbial strains that are effective for decolori- zing commonly used azo dyes in textile industrial sectors of Baddi, Himachal Pradesh (India). Moreover, the phytotoxic effect of decolorized dye solution was evaluated on chick pea and wheat seeds.

\section{Material and methods}

\section{Media and chemicals}

Congo red, methyl orange, and reactive red 198 azo dyes were purchased from Sigma-Aldrich Co. and used for bio-decolorization analyses. The other chemicals and microbial media utilized in the study were of analytical grade and the highest purity. All chemicals were acquired from Sigma-Aldrich, USA, and Hi-Media, India.

\section{Culture medium}

Bushnell and Haas medium (BH) containing $0.2 \mathrm{~g} / 1$ of $\mathrm{MgSO}_{4}, 1.0 \mathrm{~g} / \mathrm{l}$ of $\mathrm{K}_{2} \mathrm{HPO}_{4}, 0.02 \mathrm{~g} / 1$ of $\mathrm{CaCl}_{2}, 0.05 \mathrm{~g} / \mathrm{l}$ of $\mathrm{FeCl}_{3}$, and $1.0 \mathrm{~g} / 1$ of $\mathrm{NH}_{4} \mathrm{NO}_{3}$ supplemented with or without glucose $(0.4 \% \mathrm{w} / \mathrm{v})$ and yeast extract $(0.05 \% \mathrm{w} / \mathrm{v})$ was used for all experiments. The final $\mathrm{pH}$ of the medium was adjusted to 7.2 .

\section{Isolation and screening of bacterial isolates for dye decolourization}

Bacterial isolation was performed using wastewater collected from a textile industry plant located in Baddi, Himachal Pradesh, India $\left(30^{\circ} 56^{\prime} 39.4^{\prime \prime} \mathrm{N} 76^{\circ} 49^{\prime} 10.6^{\prime \prime} \mathrm{E}\right)$. The isolated bacterial cultures were screened for the highest dye decolorizing potential. Wastewater samples $(10 \mathrm{ml})$ were added to $100 \mathrm{ml} \mathrm{BH}$ broth supplemented with $100 \mathrm{mg} / \mathrm{l}$ respective dye (methyl orange, reactive red 198, or Congo red) in $250 \mathrm{ml}$ Erlenmeyer flasks. The mixtures were incubated at $37^{\circ} \mathrm{C}$ for $48 \mathrm{~h}$ at $150 \mathrm{rpm}$ in a shaking incubator for proper agitation and aeration. After incubation, $1 \mathrm{ml}$ of each bacterial culture was transferred into a fresh dye-enriched media until dye decolorization occurred. Then, $1 \mu \mathrm{l}$ of bacterial culture from the final treatment was serially diluted $\left(10^{-6}\right)$ and $100 \mu$ was spread on BH agar plates containing $100 \mathrm{mg} / \mathrm{l}$ of the respective dye. Morphologically distinct and prominent colonies with dye decolorization potential were identified and purified through repeated streaking on the same medium. The most potent dye decolorizing isolates were designated as VTK013, VTK018 for congo red; VTK035, VTK054 for methyl orange; and VTK04, VTK024 for reactive red 198. 


\section{Identification of bacterial species}

All six bacterial isolates (VTK013, VTK018, VTK035, VTK054, VTK04, and VTK024) were identified using microscopic (colony shape, color, margin, elevation, gram staining, and spore staining) and 16s rRNA gene sequencing methods. The bacterial isolates were characterized through $16 \mathrm{~S}$ rDNA sequencing and phyletic analysis. The universal bacterial primers $534 \mathrm{r}\left(5^{\prime}\right.$ - ATTA CCGCGGCTGCTGG $\left.-3^{\prime}\right)$ and $U 1517 R\left(5^{\prime}-\right.$ ACGGCTAC CTTGTTACGACTT $-5^{\prime}$ ) were used for $16 \mathrm{~S}$ rDNA amplification using PCR conditions as described previously (Srinivasan et al., 2015). ProbeBase online software and BLAST (Genbank database) were used to verify the specificity of the primers. For a multiple sequence alignment (MSA) analysis of sequences, MUSCLE alignment algorithm was applied (Karnwal, 2017a). Both phylogenetic analysis and tree creation were performed using PhyML (Dereeper et al., 2008). The isolates were tested for various biochemical assays (motility, starch hydrolysis, citrate utilization, oxidation potential, casein hydrolysis, urease production, catalase activity, gelatinase production, indole production, siderophore production, $\mathrm{H}_{2} \mathrm{~S}$ production, and various sugar utilization) as reported in Bergey's Manual of Systematic Bacteriology (Krieg and Holt, 1984).

\section{Biofilm production by adherence assay}

The biofilm production assay for VTK04, VTK013, VTK018, VTK024, VTK035, and VTK054 strains was performed in 96 -well microtitre plates using a previously reported method by Chaieb et al. (2016). All bacterial isolates were grown in a $\mathrm{BH}$ medium enriched with $2 \%$ $(\mathrm{w} / \mathrm{v})$ glucose for $24 \mathrm{~h}$ at $37^{\circ} \mathrm{C}$. Then, an aliquot of $200 \mu \mathrm{l}$ of bacterial suspension per well was dispensed into a 96 -well flat bottom microplate and incubated at $37^{\circ} \mathrm{C}$ for $24 \mathrm{~h}$. After incubation, the bacterial suspensions from all plates were removed by washing three times with phosphate buffer, followed by drying at room temperature. The bacterial adherence on the wells of microtitre plate was achieved by treatment with $95 \%$ ethanol. These wells were stained with a crystal violet solution $(1 \% \mathrm{w} / \mathrm{v})$. After $6 \mathrm{~min}$ of staining, the wells of microtitre plates were washed three times with sterile distilled water to remove the excess amount of dye from wells and air dried at room temperature for $2 \mathrm{~h}$. The optical density for stained wells was recorded using an automated ELISA reader at $570 \mathrm{~nm}$. The bacteria ad- herence as biofilm formation was measured as described by Chaieb et al. (2016) to be highly positive (OD570 $\geq 1)$, low-grade positive $(0.1 \leq$ OD570 $<1)$, or negative $($ OD570 $<0.1)$.

\section{Azo dye decolorization assay with respective dye decolorizing bacterial isolates}

The dye (color) removal assay was performed in $250 \mathrm{ml}$ Erlenmeyer flasks containing $50 \mathrm{ml}$ of pre-sterilized Bushnell and Haas medium with or without co-substrate $(0.4 \% \mathrm{w} / \mathrm{v}$ Glucose and $0.05 \% \mathrm{w} / \mathrm{v}$ yeast extract), which was supplemented with respective azo dye to a maximum strength $(100 \mathrm{mg} / \mathrm{l})$ and $10 \%(\mathrm{v} / \mathrm{v})$ respective bacterial inoculum (1 McFarland). These mixtures were incubated for 7 days at $37^{\circ} \mathrm{C}$ with continuous agitation at $150 \mathrm{rpm}$. Moreover, the control was maintained without bacterial inoculation. At every 24-h intervals, the culture broth was collected and centrifuged at $10000 \mathrm{~g}$ for $15 \mathrm{~min}$ in a cooling centrifuge at $4^{\circ} \mathrm{C}$. Dye decolorization was spectrophotometrically measured using UV-vis spectra of the supernatant at a corresponding wavelength of the respective dye solution (Congo red: $540 \mathrm{~nm}$; Methyl orange: $463 \mathrm{~nm}$; Reactive red 198: $518 \mathrm{~nm}$ ). The standardized dye solution was prepared in $\mathrm{BH}$ medium with $0-100 \mathrm{mg} / \mathrm{l}$ dye concentration and stored at $4{ }^{\circ} \mathrm{C}$ in dark after filtration through a $0.22-\mu \mathrm{m}$ membrane filter. The color removal was recorded as a percentage of the decolorization using the following equation:

$\%$ of dye decolorization $=$ (initial dye strength - final dye strength) $\times 100$ /initial dye strength

\section{Phytotoxicity of the degraded dyes solution}

An in vitro toxicity study of the dye solution before and after dye decolorization was performed as described by Chaieb et al. (2016) using chick pea (Cicer arietinum) and wheat (Triticum aestivum) seeds (10 seeds of each plate). During the in vitro study, $2 \mathrm{ml}$ of initial (dye) and decolorized $(100 \mathrm{mg} / \mathrm{l})$ solution was added to the seeds. $\mathrm{BH}$ medium without dye and bacteria was used as a control. After 10 days of incubation at room temperature, the plant growth parameters such as percentage of seed germination, radicle length, and plumule length were measured.

\section{Statistical analysis}

The differences of plant growth parameters under different treatments were analyzed using Friedman's 
test, followed by the Wilcoxon signed-rank test. $P$ values of $<0.05$ were considered to be significant.

\section{Results and discussion}

\section{Isolation and screening of bacterial isolates for dye decolorization}

Depending on the dyeing activities (stock dyeing, top dyeing, yarn dyeing, piece dyeing, dope dyeing, garment dyeing, beck, jig, pad, and jet dyeing), the textile industry refuse contains an array of different levels of various chemical dyes (Miranda Rde et al., 2013). Therefore, the microbial cultures that can be used for eliminating dyes coming from these types of effluents should have the ability to neutralize varied quantities of chemical dyes (Khandare and Govindwar, 2015; Miranda Rde et al., 2013; Muhammad Nasir Iqbal and Asgher, 2013). In this study, a total of 86 morphologically distinct bacterial colonies were isolated from a wastewater sample collected from the textile colouring industry. Out of these 86 isolates, 62 various bacterial strains showed dye decolorization ability on $\mathrm{BH}$ medium supplemented with variable concentrations of different dyes (congo red, methyl orange, and reactive red 198). The presence of microorganisms in the textile dye effluents indicates their natural adaptation and survival abilities in the presence of toxic dyes (Haq et al., 2018). On BH plates, all 62 isolates generated decolorization zones around their colonies but only six isolates had maximum zones of dye colour removal in the plate assay (from 40 to $56 \mathrm{~mm}$ ). These six isolates were designated as VTK013, VTK018 for congo red; VTK035, VTK054 for methyl orange; and VTK04, VTK024 for reactive red 198. All six bacterial isolates were characterized as described in Bergey's Manual of Systematic Bacteriology using microscopic and biochemical assays (Krieg and Holt, 1984).

\section{Colony and biochemical characteristics}

Bacteria grow fast when supplied with an abundance of nutrients. Different types of bacteria will produce different-looking colonies, some colonies may be colored, some are circular in shape, and others are irregular. The characteristics of a colony (such as shape, size, and pigmentation) are termed the colony morphology. The morphology (shape, color, elevation, and margin) of the six isolated bacterial strains is listed in Table 1 . The shape of all six bacterial colonies varied from irregular to circular. As shown in Table 1, the colony margin varied between all bacterial isolates. The color of VTK024, VTK035 was pale yellow; that of VTK018, VTK054, VTK013 was whitish; and that of VTK04 was light orange.

Various staining methods (gram staining and spore staining) were applied to observe the morphological characteristics of the bacterial isolates. The VTK013, VTK04, VTK054, and VTK035 isolates were Gram positive, whereas the remaining two strains (VTK018 and VTK024) were Gram negative and rod-shaped. The results of the microscopic and biochemical assay (such as motility, starch hydrolysis, citrate utilization, oxidation potential, casein hydrolysis, urease production, catalase activity, gelatinase production, indole production, siderophore production, $\mathrm{H}_{2} \mathrm{~S}$ production, and various sugar utilization) of all isolates are listed in Table 2.

\section{Identification of bacterial species}

Molecular characterizations of all the six isolates were performed using $16 \mathrm{~S}$ rDNA sequencing (Karnwal, 2017b). As described previously, universal $16 \mathrm{~S}$ rDNA bacterial primers $534 r\left(5^{\prime}\right.$-ATTACCGCGGCTGCTG G-3') and $\operatorname{U1517R}\left(5^{\prime}\right.$-ACGGCTACCTTGTTACGACTT- $\left.3^{\prime}\right)$ were used for $16 \mathrm{~S}$ rDNA amplification under PCR conditions (Srinivasan et al., 2015). 16S rRNA sequences of all isolates were searched online using BLAST to identify the isolates. The BLAST search of the 16S rRNA sequences ofVTK04, VTK013, VTK018, VTK024, VTK035, and VTK054 isolates showed maximum sequence similarity with Enterococcus faecalis (98\%, genbank ID: NR_114782.1), Staphylococcus aureus (97\%, genbank ID: NR_113956.1), Pseudomonas aeruginosa (98\%, genbank ID: NR_026078.1), Proteus mirabilis (97\%, genbank ID: NR_043997.1), Bacillus cereus (96\%, genbank ID:NR_074540.1), and Enterococcus faecium (95\%, genbank ID: NR_114742.1), respectively. The MUSCLE alignment algorithm was applied for a multiple sequence alignment (MSA) analysis between sequences collected from BLAST. On the basis of the MSA results, for phylogenetic analysis, the MEGA X software (Kimura 2-parameter substitution model and neighbor-joining statistical method) was applied for computing the evolutionary distance of the stress tolerant strains. The phylogenetic dendograms of the isolates are shown in Figure 1. 
Table 1. Colony characteristics of selected bacterial isolates

\begin{tabular}{l|c|c|c|c|c}
\hline \multicolumn{1}{c|}{ Bacterial isolate } & Shape & Color & Margin & Elevation & Gram stain \\
\hline VTK04 & cocci & light orange & entire & raised & + \\
\hline VTK013 & cocci & whitish & irregular & convex & + \\
\hline VTK018 & rod & whitish & unbonate & convex & - \\
\hline VTK024 & rod & pale yellow & regular & raised & - \\
\hline VTK035 & rod & pale yellow & unbonate & convex & + \\
\hline VTK054 & cocci & whitish & entire & convex & + \\
\hline
\end{tabular}

Table 2. Microscopic and biochemical properties of bacterial isolates

\begin{tabular}{|c|c|c|c|c|c|c|}
\hline \multirow{2}{*}{ Tests } & \multicolumn{6}{|c|}{ Test microorganism } \\
\hline & VTK04 & VTK013 & VTK018 & VTK024 & VTK035 & VTK054 \\
\hline Gram staining & + ve & + ve & -ve & - ve & + ve & +ve \\
\hline Spore production & - & - & - & - & + & - \\
\hline Motility & - & - & + & + & + & - \\
\hline Starch hydrolysis & - & + & + & - & + & + \\
\hline Citrate utilization & + & + & + & + & + & - \\
\hline Oxidation reaction & + & - & + & - & + & - \\
\hline Casein hydrolysis & - & - & - & + & + & - \\
\hline Urease production & - & + & - & + & - & - \\
\hline Catalase test & - & + & + & + & + & - \\
\hline Gelatinase production & - & + & + & + & + & + \\
\hline Indole production & + & - & + & - & - & - \\
\hline Siderophore production & - & - & - & + & - & + \\
\hline $\mathrm{H}_{2} \mathrm{~S}$ production & + & - & - & + & + & - \\
\hline Glucose & + & + & - & + & + & + \\
\hline Mannitol & - & + & + & - & + & + \\
\hline Fructose & - & + & + & - & + & + \\
\hline Arabinose & - & - & - & - & + & - \\
\hline Trehalose & + & + & + & + & + & - \\
\hline Glycerol & $\mathrm{D}$ & + & - & + & + & - \\
\hline Xylose & - & - & - & + & + & - \\
\hline
\end{tabular}

\section{The ability to produce biofilm of tested isolates} using adherence assay

A biofilm is an assemblage of microbial cells that are irreversibly associated (not removed by gentle rinsing) with a surface and enclosed in a matrix of primarily polysaccharide material (Belouhova et al., 2014). Microorganisms attach to surfaces and develop biofilms, and biofilm-associated cells can be distinguished from their suspended counterparts because of their generation of an extracellular polymeric substance (EPS) matrix, reduced growth rates, and the up- and down-regulation of specific genes (Cerron et al., 2015). Biofilms may form on a wide variety of surfaces such as living tissues, indwelling medical devices, industrial or potable water system piping, or natural aquatic systems. The selection 
A

A NR 125485.1 Enterococcus ureilyticus strain CCM $462916 \mathrm{~S}$ ribosomal RNA partial sequence

LNR 042405.1 Enterococcus silesiacus strain R-23712 16 S ribosomal RNA partial sequence

- NR 108137.1 Enterococcus rotai strain CCM 4630 16S ribosomal RNA partial sequence

44 NR 028794.1 Enterococcus moraviensis strain 330 16S ribosomal RNA gene partial sequence - NR 113937.1 Enterococcus moraviensis strain NBRC 100710 16S ribosomal RNA gene partial sequence - NR 113936.1 Enterococcus haemoperoxidus strain NBRC 100709 16S ribosomal RNA gene partial sequence NR 042406.1 Enterococcus termitis strain LMG 8895 16S ribosomal RNA partial sequence NR 159231.1 Enterococcus wangshanyuanii strain MN05 16S ribosomal RNA partial sequence

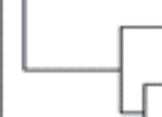
NR 117043.1 Enterococcus rivorum strain S299 16S ribosomal RNA gene partial sequence -NR 114782.1 Enterococcus faecalis strain LMG 7937 16S ribosomal RNA partial sequence LVTK04

NR 075022.1 Enterococcus hirae strain ATCC 9790 16S ribosomal RNA partial sequence

B

NR 037007.2 Staphylococcus aureus strain S33 R 16S ribosomal RNA complete sequence<smiles>CCCCCCCCCCCCCCCCCCCCCCCCCCCCCCCCCCCC</smiles>
VTK013

NR 113956.1 Staphylococcus aureus strain NBRC 100910 16S ribosomal RNA gene partial sequence NR 115606.1 Staphylococcus aureus strain ATCC 12600 16S ribosomal RNA gene partial sequence NR 043146.1 Staphylococcus simiae strain CCM 7213 16S ribosomal RNA gene partial sequence - NR 118450.1 Staphylococcus petrasii strain CCM 8418 16S ribosomal RNA gene partial sequence

- NR 136463.1 Staphylococcus petrasii subsp. pragensis strain CCM 8529 16S ribosomal RNA partial sequence - NR 113957.1 Staphylococcus epidermidis strain NBRC 100911 16S ribosomal RNA gene partial sequence - NR 036904.1 Staphylococcus epidermidis strain Fussel 16S ribosomal RNA gene partial sequence NR 113405.1 Staphylococcus saccharolyticus strain JCM 1768 16S ribosomal RNA gene partial sequence NR 027519.1 Staphylococcus capitis subsp. urealyticus strain MAW 8436 16S ribosomal RNA gene partial sequence - NR 024665.1 Staphylococcus caprae strain ATCC 35538 16S ribosomal RNA gene partial sequence - NR 113348.1 Staphylococcus capitis strain JCM 2420 16S ribosomal RNA gene partial sequence

C $\quad$ NR 026078.1 Pseudomonas aeruginosa strain DSM 50071 16S ribosomal RNA complete sequence - VTK018
NR 117678.1 Pseudomonas aeruginosa strain DSM 50071 16S ribosomal RNA gene partial sequence
NR 043289.1 Pseudomonas otitidis strain MCC10330 16 S ribosomal RNA partial sequence
NR 112062.1 Pseudomonas resinovorans strain ATCC 1423516 r ribosomal RNA partial sequence
NR 043419.1 Pseudomonas alcaligenes strain IAM 12411 16S ribosomal RNA partial sequence
NR 103934.2 Pseudomonas stutzeri strain ATCC 1758816 ribosomal RNA complete sequence
NR 043421.1 Pseudomonas mendocina strain NCIB 10541 16S ribosomal RNA partial sequence
NR 042435.1 Pseudomonas nitroreducens strain IAM 143916 S ribosomal RNA gene partial sequence 


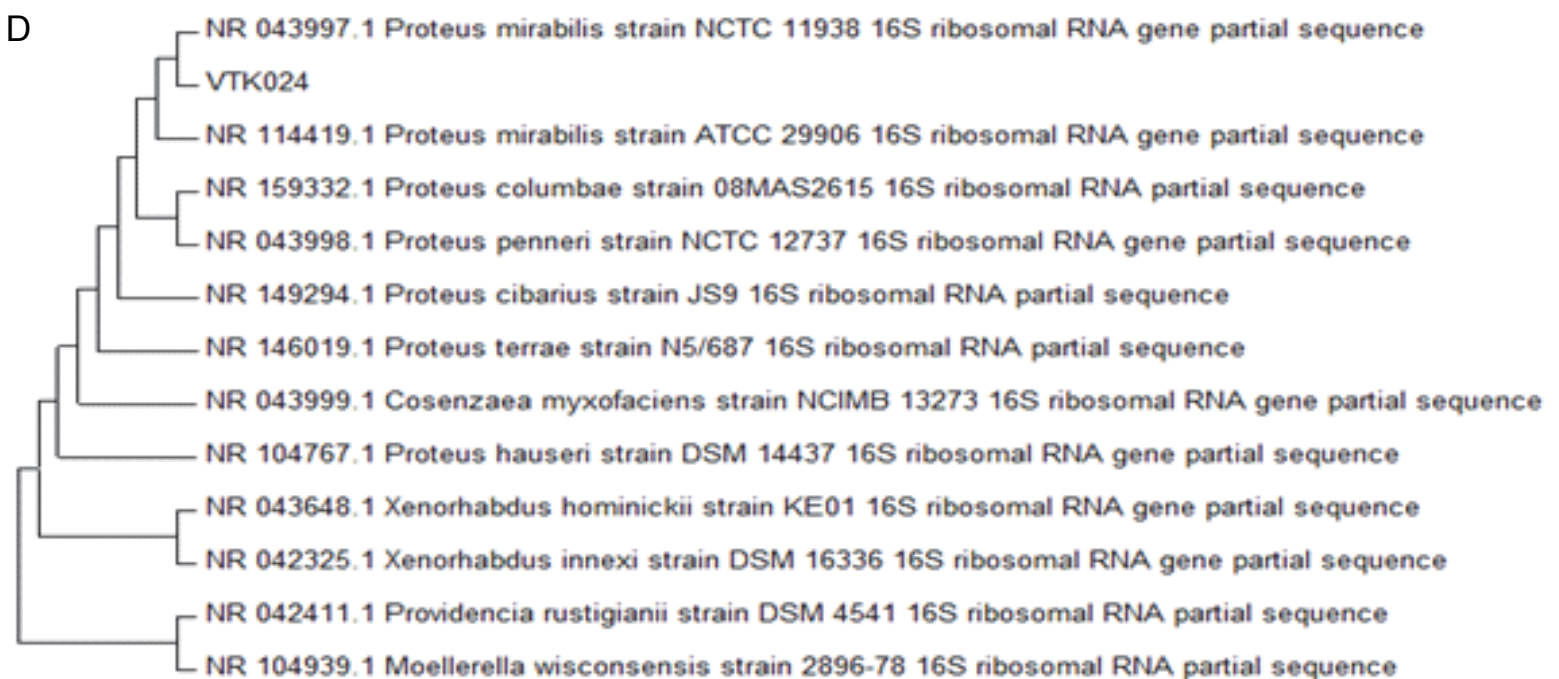

E $\quad$ NR 157733.1 Bacillus pacificus strain MCCC 1A06182 16S ribosomal RNA partial sequence
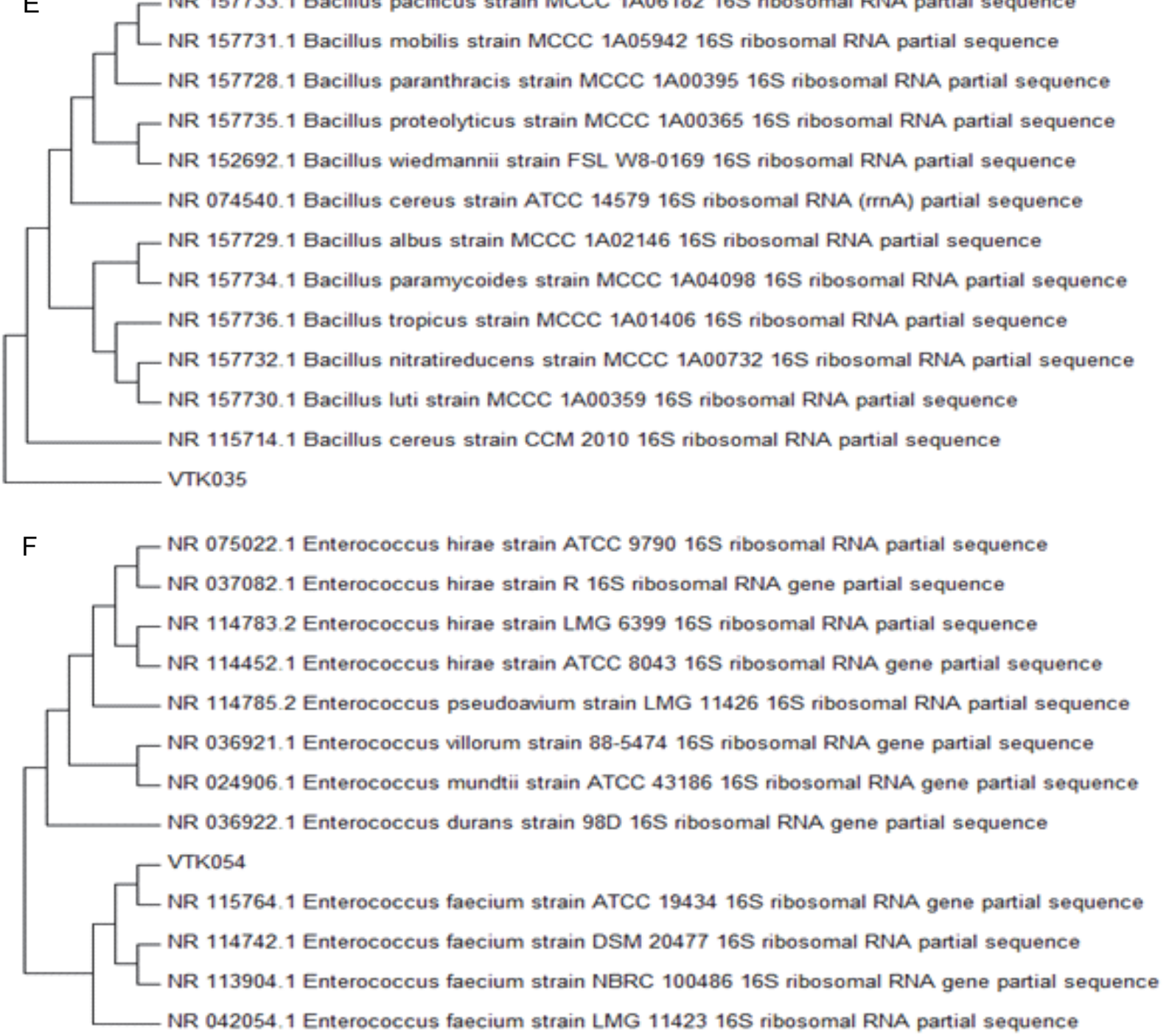

Fig. 1. A) Phylogenetic tree showing close neighboring of VTK04 with Enterococcus faecalis strain LMG 7937; B) VTK013 with Staphylococcus aureus strain S33 R; C) VTK18 with Pseudomonas aeruginosa DSM 50071; D) VTK024 with Proteus mirabilis NCTC 11938; E) VTK035 with Bacillus cereus CCM 2010; and F) VTK054 with Enterococcus faecium strain ATCC 19434 
of the most appropriate method for textile azo dye decolorization is based on advantages in terms of economy, practicality, and efficiency. Biofilm processes degrade pollutants (such as dye, oil, or waste water) to a higher extent compared to active sludge treatment. They have better resistance to fluctuations in loads, starvation periods, and washouts (Chandran and Das, 2011). In the previous investigation (Belouhova et al., 2014), the bacteria from genus Pseudomonas played an important role in the adaptation of biofilms for the biodegradation of azo dyes. This study focused on increasing the potential of tested isolates to generate stable bonding with the abiotic surface in the form of a biofilm (Rajendran et al., 2015). A bacterial adherence study on the abiotic surface was investigated using 96-well microtitre polystyrene plates, as reported by Chaieb et al. (2016). The results confirmed that VTK013, VTK054, and VTK024 have the potential to form stable biofilms on abiotic surfaces (OD570 $=1.37,2.38$ and 1.52 respectively). The VTK035 and VTK018 isolated showed a lower adherence potential (OD570 $=0.41$ and 0.38 , respectively) compared to VTK04 $(\mathrm{OD} 570=0.87)$. Anjaneya et al. $(2013)$ reported that bacterial biofilms are more efficient in docolorizing Amaranth dye at three different dye concentrations (200, 400 , and $600 \mathrm{mg} / \mathrm{l})$. Wong and Yuen (1996) reported that the strains of Klebsiella pneumoniae RS-13 and Acetobacter liquefaciens S-1 have the ability to decolorize the azo dye methyl red as well as its possible suitability for treating azo dye-containing textile effluents. The aerobicanaerobic decolorization and degradation of red HE7B in the textile effluent was achieved using Pseudomonas desmolyticum (Cariell et al., 1995; Ogawa and Yatome, 1990). Zissi et al. (1997) reported that Bacillus subtilis could be used to degrade a specific azo dye, i.e., paminobenzene. Coughlin et al. (1999) reported that the Sphingomonas sp., strain 1CX had the ability to decolorize $20 \mathrm{mg} / 1$ orange II, acid orange 8 and 10, acid red 4 , and acid red dyes.

\section{Dye decolorization assay}

The wastewater from the textile industry contains a large amount of coloring chemicals (Yuan et al., 2016). In this study, bacterial strains were examined for dye decolorization potential using three textile azo dyes (congo red, methyl orange, and reactive red 198). Selected bacterial isolates showed a variable dye color removal potential at $100 \mathrm{mg} / \mathrm{l}$ concentration of the respec-

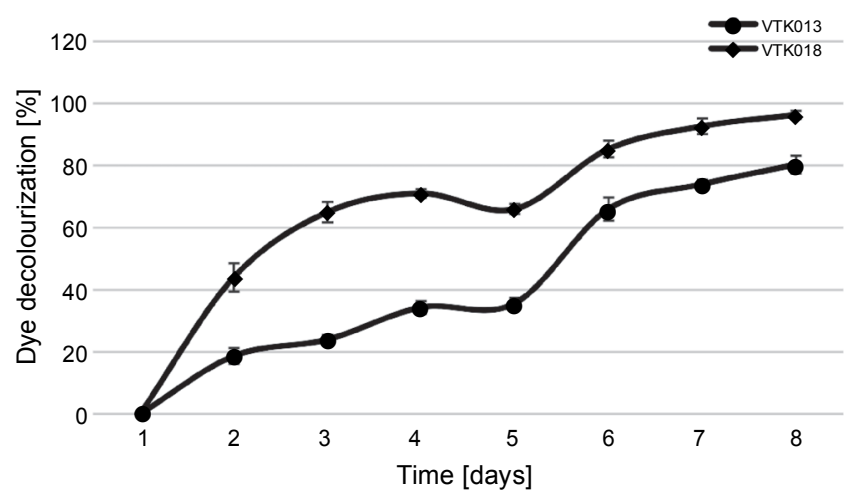

Fig. 2. Decolorization of congo red by bacterial isolates

tive dyes. The variable rate of color removal with experimental azo dyes demonstrated that the rate of reduction considerably differed between dye/organism combination (Chauhan et al., 2017; Nisar et al., 2017), indicating the unique reduction potential of the bacteria as well as a different susceptibility of dyes towards reductases (Karim et al., 2018). Previously, studies (Neoh et al., 2015; Skariyachan et al., 2016; Vats and Mishra, 2017) reported that the efficiency of dye decolorization was affected by availability, survival potential, acclimatization, and efficacy of biocatalysts synthesized by microorganisms. In our experiments, the bacteria grown on $\mathrm{BH}$ medium (magnesium sulphate $(0.200 \mathrm{~g} / \mathrm{l})$; calcium chloride $(0.020 \mathrm{~g} / \mathrm{l})$; monopotassium phosphate $(1.0 \mathrm{~g} / \mathrm{l})$; dipotassium phosphate $(1.0 \mathrm{~g} / \mathrm{l})$; ammonium nitrate $(1.0 \mathrm{~g} / \mathrm{l})$; ferric chloride $(0.05 \mathrm{~g} / \mathrm{l})$; and agar $(20.0 \mathrm{~g} / \mathrm{l})$, $\mathrm{pH}$ 7.0) supplemented with carbon and nitrogen substrates (glucose and yeast extract) showed considerable decolorization of azo dyes (congo red: 80-96\%; methyl orange: $75-100 \%$, and reactive red 198: 88-90\%; Fig. 2, Fig. 3, and Fig. 4). The BH medium devoid of any carbon substrate does not support decolorization, which indicated a complete dependence of bacteria on carbon and nitrogen sources for inducing dye decolorization (Karim et al., 2018). Note that azo dyes are deficient in carbon sources, and the microbial degradation of dyes without any supplement of carbon or nitrogen sources is very difficult (Bilal and Asgher, 2015; Vats and Mishra, 2017); therefore, a carbon source is necessary for obtaining good decolorization results. The results of the present study showed that a medium composition plays a critical role in dye decolorization. Furthermore, the availability of an electron donor in the culture medium is a critical component for reducing azo dyes by bacteria (Mnif et al., 


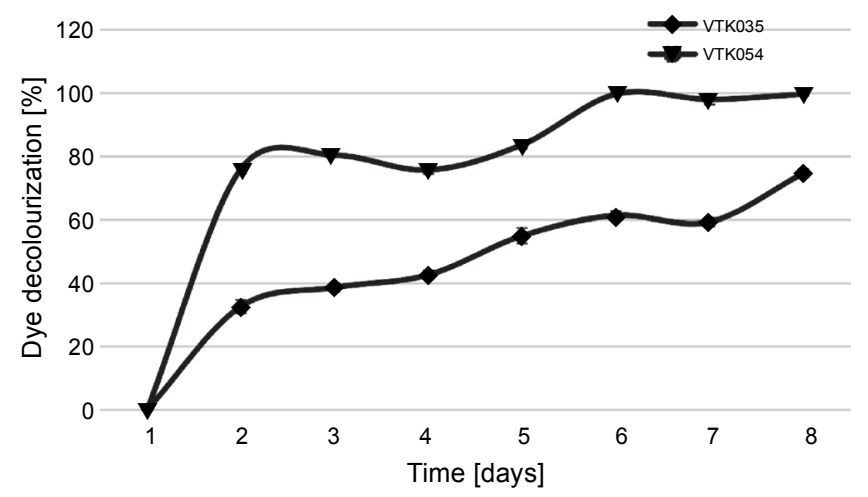

Fig. 3. Decolorization of methyl orange by bacterial isolates

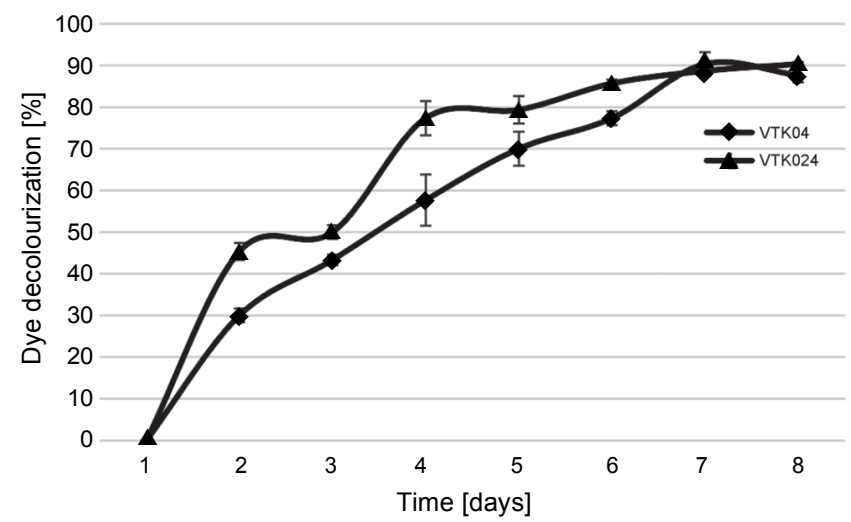

Fig. 4. Decolorization of reactive red 198 by bacterial isolates

2015). Many studies have confirmed that glucose and yeast extract can work as electron donors for dye degrading enzymes and enhance the dye degradation process (Bilal and Asgher, 2015). The decolorization of congo red at a concentration of $100 \mathrm{mg} / 1$ by VTK013 and VTK018 isolates was recorded at $80 \%$ and $96 \%$, respectively, after 8 days of incubation (Fig. 2). Furthermore, the dye decolorization by the VTK013 isolate reached $34 \%$ after three days of incubation and stabilized at the $4^{\text {th }}$ day of incubation. On the $5^{\text {th }}$ day, an increase in the decolorization potential of VTK013 was observed from $37 \%$ to $67 \%$. The VTK018 results show a variation in dye decolorization after the first to seventh day of incubation. Furthermore, after one day of incubation, the decolorization was recorded with an efficiency of $44 \%$. Moreover, we observed efficient decolourization on the $4^{\text {th }}, 5^{\text {th }}$, and $6^{\text {th }}$ day. Finally, on the $8^{\text {th }}$ day, maximum decolorization (with $96 \%$ efficiency) was noted for congo red, as shown in Figure 2. Figure 3 shows the decolorization of methyl orange at a concentration of $100 \mathrm{mg} / \mathrm{l}$ by selected bacterial isolates. On the first day, no de- colorization by the isolates VTK054 and VTK035 was observed. However, with the increase in the incubation time, a significant decolorization of methyl orange was noted for both bacterial isolates. After five days of incubation, the bacterial isolate VTK054 showed the highest dye decolorization with $100 \%$ efficiency. Initially, on the $2^{\text {nd }}$ day and $5^{\text {th }}$ day, the decolorization efficiency for VTK054 increased from $76 \%$ to $84 \%$ and reached $100 \%$ on the $6^{\text {th }}$ day under controlled conditions. The isolate VTK035 showed the maximum dye decolorization of $75 \%$ after seven days of incubation. Moreover, the dye decolorization after one day of incubation for methyl orange with VTK053 was recorded as 33\% and reached $61 \%$ on the $6^{\text {th }}$ day of the experiment. A small drop in the decolorization efficiency was observed on the $7^{\text {th }}$ day with 59\% with VTK035 isolate, as shown in Figure 3. In this study, maximum decolourization (90\%) for reactive red 198 was observed for the VTK04 bacterial isolate on the $7^{\text {th }}$ day of incubation. As shown in Figure 4, a sharp increase from $53 \%$ to $77 \%$ was observed for the VTK04 dye decolorization efficiency after the $2^{\text {nd }}$ day of incubation. A small decreased in dye decolorization efficiency was recorded for VTK04 on the $8^{\text {th }}$ day from $90 \%$ to $88 \%$. However, as shown in Figure 4, the isolate VTK024 presented $90 \%$ dye decolorization on the $8^{\text {th }}$ day of incubation. Finally, on the $3^{\text {rd }}$ day, decolorization was recorded with $50 \%$ efficiency, which then changed to $86 \%$ on the $6^{\text {th }}$ day of experiment for VTK024. The divergence in the decolorization efficiency was caused by the variation in the selectivity of bacterial isolates; the composition and complexity of chemical dyes, specifically relating to the type; and the placement of substituents (para and ortho) in the aromatic rings and the interaction with $\mathrm{R}-\mathrm{N}=\mathrm{N}-\mathrm{R}$ bond as mentioned by various researchers (Chaieb et al., 2016; Jha et al., 2016; Mnif et al., 2016). A majority of the bacteriological genera, i.e., Enterococcus, Staphylococcus, Pseudomonas, Proteus, and Bacillus, which were tested in this study, have been published earlier (Chaieb et al., 2016; Neifar et al., 2016). Many researchers (Karim et al., 2018; Wan et al., 2017) reported the presence of Bacillus and Enterococcus genus as dye decolorizing organisms on a regular basis in wastewater effluents. The potential of Proteus sp. such as Proteus vulgaris NCIM 2027 as a dye-decolorizing agent for textile dye degradation has been investigated previously (Saratale et al., 2011). These studies revealed the occurrence of different microbial genera, which were characterized as 
Table 3. Phytotoxicity study of azo dyes and their degradation product

\begin{tabular}{|c|c|c|c|c|c|c|}
\hline \multirow[b]{2}{*}{ Azo dyes } & \multirow{2}{*}{$\begin{array}{l}\text { Bacterial } \\
\text { strain }\end{array}$} & \multirow{2}{*}{$\begin{array}{c}\text { Parameters } \\
\text { studied }\end{array}$} & \multicolumn{2}{|c|}{ Chick pea } & \multicolumn{2}{|c|}{ Wheat } \\
\hline & & & $\begin{array}{c}\text { before } \\
\text { treatment }\end{array}$ & $\begin{array}{c}\text { after } \\
\text { biodegradation }\end{array}$ & $\begin{array}{l}\text { before } \\
\text { treatment }\end{array}$ & $\begin{array}{c}\text { after } \\
\text { biodegradation }\end{array}$ \\
\hline \multirow{6}{*}{ Congo Red } & \multirow{3}{*}{ VTK013 } & $\%$ seed germination & 90 & 100 & 90 & 100 \\
\hline & & plumule length $[\mathrm{cm}]$ & $5.02 \pm 0.43$ & $10.25 \pm 1.04$ & $4.78 \pm 0.83$ & $8.81 \pm 1.35$ \\
\hline & & radicle length $[\mathrm{cm}]$ & $2.02 \pm 0.53$ & $5.2 \pm 0.72$ & $2.42 \pm 0.29$ & $5.46 \pm 0.51$ \\
\hline & \multirow{3}{*}{ VTK018 } & $\%$ seed germination & 90 & 100 & 90 & 100 \\
\hline & & plumule length $[\mathrm{cm}]$ & $5.02 \pm 0.43$ & $11.10 \pm 1.21$ & $4.78 \pm 0.83$ & $8.51 \pm 1.03$ \\
\hline & & radicle length $[\mathrm{cm}]$ & $2.02 \pm 0.53$ & $5.7 \pm 0.19$ & $2.42 \pm 0.29$ & $7.3 \pm 0.22$ \\
\hline \multirow{6}{*}{ Methyl orange } & \multirow{3}{*}{ VTK035 } & $\%$ seed germination & 80 & 100 & 80 & 100 \\
\hline & & plumule length $[\mathrm{cm}]$ & $3.09 \pm 0.46$ & $7.92 \pm 1.04$ & $3.9 \pm 0.38$ & $10.2 \pm 1.36$ \\
\hline & & radicle length $[\mathrm{cm}]$ & $3.01 \pm 0.74$ & $4.1 \pm 0.34$ & $2.4 \pm 0.89$ & $5.5 \pm 0.82$ \\
\hline & \multirow{3}{*}{ VTK054 } & $\%$ seed germination & 80 & 100 & 80 & 100 \\
\hline & & plumule length $[\mathrm{cm}]$ & $3.09 \pm 0.46$ & $8.92 \pm 0.28$ & $3.9 \pm 0.38$ & $8.1 \pm 1.42$ \\
\hline & & radicle length $[\mathrm{cm}]$ & $3.01 \pm 0.74$ & $5.2 \pm 0.54$ & $2.4 \pm 0.89$ & $3.9 \pm 0.32$ \\
\hline \multirow{6}{*}{ Reactive red 198} & \multirow{3}{*}{ VTK04 } & $\%$ seed germination & 90 & 100 & 90 & 100 \\
\hline & & plumule length $[\mathrm{cm}]$ & $3.98 \pm 0.29$ & $9.64 \pm 1.23$ & $3.78 \pm 0.52$ & $8.55 \pm 1.2$ \\
\hline & & radicle length $[\mathrm{cm}]$ & $2.8 \pm 0.41$ & $5.23 \pm 0.13$ & $1.98 \pm 0.28$ & $5.88 \pm 0.78$ \\
\hline & \multirow{3}{*}{ VTK024 } & $\%$ seed germination & 90 & 100 & 90 & 100 \\
\hline & & plumule length $[\mathrm{cm}]$ & $3.98 \pm 0.29$ & $7.25 \pm 0.37$ & $3.78 \pm 0.52$ & $8.98 \pm 0.72$ \\
\hline & & radicle length $[\mathrm{cm}]$ & $2.8 \pm 0.41$ & $4.8 \pm 1.12$ & $1.98 \pm 0.28$ & $9.2 \pm 1.78$ \\
\hline \multirow{3}{*}{ No dye } & \multirow{3}{*}{ BH medium } & $\%$ seed germination & 100 & & 100 & \\
\hline & & plumule length $[\mathrm{cm}]$ & $12.85 \pm 1.67$ & & $13.61 \pm 0.65$ & \\
\hline & & radicle length $[\mathrm{cm}]$ & $14.37 \pm 1.28$ & & $9.25 \pm 1.24$ & \\
\hline
\end{tabular}

Values represent the mean of three replicates \pm standard error of the mean

Bacillus sp., Alkaligenes sp., and Aeromonas sp., in various soil and wastewater samples obtained from the neighboring locations of fabric-coloring companies and waste materials management dumping sites (Mnif et al., 2016; Ng et al., 2014). However, bacterial isolates, i.e., Staphylococcus aureus, Pseudomonas aeruginosa, and Enterococcus faecalis, are considered as pathogens for humans, and their application for treating textile effluents might create major medical issues, particularly if these isolates are not correctly maintained.

\section{Phytotoxicity study results}

For environment sustainability and reusability in agricultural practice, it is necessary to study the toxic nature of decolorized solutions (Chen et al., 2018). In this study, after seven days of dye decolorization experi- ments, a toxicity study for all six decolorized dye solutions before and after dye decolorization was performed, as described by Chaieb et al. (2016). The results of the phytotoxicity study are shown in Table 3 . Fresh BH medium without any dye (positive control) did not show any negative effect on the germination of seeds (chick pea and wheat) and both seeds reached $100 \%$ germination in the in vitro study. In the phytotoxic studies, a similar effect on the percentage of germination of both crop seeds was observed with a decolorized dye solution. A decolourized dye solution showed a positive impact on the root and shoot growth compared to the non-decolorized dye solution for both crop seeds. A decolorized dye solution of VTK013, VTK018, and VTK04 strains increased chickpea shoot growth to $>52 \%$ over the nondecolorized dye medium. A higher shoot growth in chick- 
pea seeds was observed with the decolorized dye solution of VTK035 (60\%) and VTK054 (65\%) over non-decolorized dye medium (Table 3 ). In this study, a positive impact of a dye-decolorized medium on wheat shoot growth was recorded. Note that, after seven days of incubation with a bacterial solution, a decolorized medium promoted/induced better wheat shoot growth, which ranged from $43 \%$ to $62 \%$, compared to when using a non-decolorized medium, as shown in Table 3 . An earlier study (Telke et al. 2010) demonstrated that Su-EBT solutions containing azo dyes biodegraded by Pseudomonas sp. decreased the dye toxicity on the growth of great millet (Sorghum bicolor), mung bean (Vigna radiata), lentil (Lens culinaris), and rice (Oryza sativa) plants. In this study, the effect of non-decolorized and decolorized dye media on chickpea and wheat seeds was tested. The VTK035 isolate increased chick pea root growth to $36 \%$ over the non-treated dye medium. While VTK054, VTK04, and VTK024 showed improved root growth from $41 \%$ to $49 \%$, compared to the VTK035-decolorized and non-treated dye medium. The maximum root growth (28\%) for wheat was observed with the VTK024 bacterial isolate. A similar observation was performed for VTK04- and VTK018-based dye-decolorized medium, in which the root growth was recorded as $66 \%$ and $62 \%$, respectively. Moreover, there was an increase in the root growth compared with that observed for a non-decolorized medium, as shown in Table 3. Saratale et al. (2015) reported the non-toxic nature of a decolorized dye solution on sorghum and black gram. Furthermore, the results of Wilcoxon signed-rank test demonstrated a statistically considerable variation in the plumule and radicle growth between the treated crop seeds $(P<0.05)$ and control seeds (Table 3$)$.

\section{Conclusions}

Pollution in any form is highly dangerous for the sustainability of the environment. Effluents from textile dyeing industries have created an alarming situation for both aquatic and terrestrial life. Environmental sustainability depends on the remediation of textile effluents through physical, chemical, or biological processes. In this study, the screening of dye-decolorizing bacteria isolates from textile effluents and their dye decolorization efficiency on three azo dyes was investigated. The results demonstrated the support of the biological re- mediation of azo dyes and made it a cost-effective process for the decolorization of textile dye effluents. The results of our study clearly demonstrate that bacterial isolates did not use azo dyes as carbon sources, whereas glucose and yeast extract supplemented into media were used by bacterial isolates. The treated dye effluents were tested for phytotoxic properties to determine the possibility of reusing them for agricultural irrigation purposes. The results of the phytotoxic study demonstrated that the remediated effluent showed a non-toxic effect on chickpea and wheat seeds as well as their germination. However, the detoxification mechanism must be improved further to enhance the use of the remediated effluents with other plants in field.

\section{Acknowledgement}

I am very thankful to the Bhojia Institute of Life Sciences, Budh, Baddi, H.P., India, for the technical support that allowed me to complete this study, as well as for the help extended to me in all steps of my research.

\section{References}

Anjaneya O., Shrishailnath S.S., Guruprasad K., Nayak A.S., Mashetty S.B., Karegoudar T.B. (2013) Decolourization of Amaranth dye by bacterial biofilm in batch and continuous packed bed bioreactor. Int. Biodeterior. Biodegradation. 79: 64-72.

Belouhova M., Schneider I., Chakarov S., Ivanova I., Topalova Y. (2014) Microbial community development of biofilm in Amaranth decolourization technology analysed by FISH. Biotechnol. Biotechnol. Equip. 28(4): 635-642.

Bilal M., Asgher M. (2015) Dye decolourization and detoxification potential of ca-alginate beads immobilized manganese peroxidase. BMC Biotechnol. 15: 111.

Cariell C.M., Barclay S.J., Naidoo N., Buckley C.A., Mulholland D.A., Senior E. (1995) Microbial decolourisation of a reactive azo dye under anaerobic conditions. Water S.A. 21: 61-69.

Celebi M., Kaya M.A., Altikatoglu M., Yildirim H. (2013) Enzymatic decolourization of anthraquinone and diazo dyes using horseradish peroxidase enzyme immobilized onto various polysulfone supports. Appl. Biochem. Biotechnol. 171(3): 716-730.

Cerron L.M., Romero-Su arez D., Vera N., Ludena Y., Gretty V.K., Gutierrez-Correa M. (2015) Decolourization of textile Reactive dyes and effluents by biofilms of Trametes polyzona LMB-TM5 and Ceriporia sp. LMB-TM1 isolated from the Peruvian Rainforest. Water. Air. Soil. Pollut. 226: 1-13.

Chaieb K., Hagar M., Radwan N.R.E. (2016) Biodegradation and decolourization of azo dyes by adherent staphylococcus lentus strain. Appl. Biol. Chem. 59(3): 405-413. 
Chandran P., Das N. (2011) Degradation of diesel oil by immobilized Candida tropicalis and biofilm formed on gravels. Biodegradation, 22(6): 1181-1189.

Chauhan P.S., Goradia B., Saxena A. (2017) Bacterial laccase: Recent update on production, properties and industrial ap plications. 3 Biotech. 7(5): 323.

Chen Y., Feng L., Li H., Wang Y., Chen G., Zhang Q. (2018) Biodegradation and detoxification of direct black $g$ textile dye by a newly isolated thermophilic microflora. Bioresour. Technol. 250: 650-657.

Coughlin M.F., Kinkle B.K., Bishop P.L. (1999) Degradation of azo dyes containing aminonaphthol by Sphingomonas sp. strain 1CX. J. Ind. Microbiol. Biotechnol. 23: 341-346.

Dereeper A., Guignon V., Blanc G., Audic S., Buffet S., Chevenet F., Dufayard J.F., Guindon S., Lefort V., Lescot M. et al. (2008) Phylogeny. Fr: Robust phylogenetic analysis for the non-specialist. Nucleic. Acids. Res. 36(suppl. 2): W465-W469.

Haq I., Raj A., Markandeya (2018) Biodegradation of azure- $b$ dye by serratia liquefaciens and its validation by phytotoxicity, genotoxicity and cytotoxicity studies. Chemosphere 196: 58-68.

Jha P., Jobby R., Desai N.S. (2016) Remediation of textile azo dye acid red 114 by hairy roots of ipomoea carnea jacq. and assessment of degraded dye toxicity with human keratinocyte cell line. J. Hazard. Mater. 311: 158-167.

Karim M.E., Dhar K., Hossain M.T. (2018) Decolourization of textile reactive dyes by bacterial monoculture and consortium screened from textile dyeing effluent. Genet. Eng. Biotechnol. J. 16(2): 375-380.

Karnwal A. (2017a) Biosurfactant production by kocuria rosea and arthrobacter luteolus using sugar cane waste as substrate. II Ponte. 73(2): 20-29.

Karnwal A. (2017b) Isolation and identifi cation of plant growth promoting rhizobacteria from maize (zea mays 1.) rhizosphere and their plant growth promoting eff ect on rice (oryza sativa 1.). J. Plant. Prot. Res. 57(2): 144-151.

Khandare R.V., Govindwar S.P. (2015) Phytoremediation of textile dyes and effluents: current scenario and future prospects. Biotechnol Adv. 33(8): 1697-1714.

Krieg N.R., Holt J.G. (1984) Bergey's manual of systematic bacteriology. Baltimore, London: Williams \& Wilkins.

Liu G., Zhou J., Meng X., Fu S.Q., Wang J., Jin R., Lv H. (2013) Decolourization of azo dyes by marine shewanella strains under saline conditions. Appl. Microbiol. Biotechnol. 97(9): 4187-4197.

Ma X., Liu L., Li Q., Liu Y., Yi L., Ma L., Zhai C. (2017) Highlevel expression of a bacterial laccase, cueo from escherichia coli $\mathrm{k} 12$ in pichia pastoris gs 115 and its application on the decolourization of synthetic dyes. Enzyme. Microb. Technol. 103: 34-41.

Miranda R.C., Gomes E.B., Pereira N. Jr., Marin-Morales M.A., Machado K.M., Gusmao N.B. (2013) Biotreatment of textile effluent in static bioreactor by curvularia lunata urm 6179 and phanerochaete chrysosporium urm 6181. Bioresour. Technol. 142: 361-367.
Mnif I., Fendri R., Ghribi D. (2015) Biosorption of congo red from aqueous solution by bacillus weihenstephanensis ri12; effect of spb1 biosurfactant addition on biodecolourization potency. Water. Sci. Technol. 72(6): 865-874.

Mnif I., Maktouf S., Fendri R., Kriaa M., Ellouze S., Ghribi D. (2016) Improvement of methyl orange dye biotreatment by a novel isolated strain, aeromonas veronii gri, by spb1 biosurfactant addition. Environ. Sci. Pollut. Res. Int. 23(2): 1742-1754.

Muhammad Nasir Iqbal H., Asgher M. (2013) Decolourization applicability of sol-gel matrix immobilized manganese peroxidase produced from an indigenous white rot fungal strain ganoderma lucidum. BMC Biotechnol. 13: 56.

Neifar M., Chouchane H., Mahjoubi M., Jaouani A., Cherif A. (2016) Pseudomonas extremorientalis bu118: A new salttolerant laccase-secreting bacterium with biotechnological potential in textile azo dye decolourization. 3 Biotech. 6(1): 107.

Neoh C.H., Lam C.Y., Lim C.K., Yahya A., Bay H.H., Ibrahim Z., Noor Z.Z. (2015) Biodecolourization of recalcitrant dye as the sole sourceof nutrition using curvularia clavata $n z 2$ and decolourization ability of its crude enzymes. Environ. Sci. Pollut. Res. Int. 22(15): 11669-11678.

Ng I.S., Chen T., Lin R., Zhang X., Ni C., Sun D. (2014) Decolourization of textile azo dye and congo red by an isolated strain of the dissimilatory manganese-reducing bacterium shewanella xiamenensis bc01. Appl. Microbiol. Biotechnol. 98(5): 2297-2308.

Nisar N., Aleem A., Saleem F., Aslam F., Shahid A., Chaudhry H., Malik K., Albaser A., Iqbal A., Qadri R. et al. (2017) Reduction of reactive red 241 by oxygen insensitive azoreductase purified from a novel strain staphylococcus ku898286. PLoS One. 12(5): e0175551.

Ogawa T., Yatome C. (1990) Biodegradation of azo dyes in multistage rotating biological contactor immobilized by assimilating bacteria. Bull. Environ. Contam. Toxicol. 44: 561-566.

Paz A., Carballo J., Perez M.J., Dominguez J.M. (2017) Biological treatment of model dyes and textile wastewaters. Chemosphere. 181: 168-177.

Rajendran R., Prabhavathi P., Karthiksundaram S., Pattab S., Kumar S.D., Santhanam P. (2015) Biodecolourization and bioremediation of denim industrial wastewater by adapted bacterial consortium immobilized on inert polyurethane foam (puf) matrix: A first approach with biobarrier model. Pol. J. Microbiol. 64(4): 329-338.

Saratale R.G., Saratale G.D., Chang J.S., Govindwar S.P. (2011) Decolourization and degradation of reactive azo dyes by fixed bed bioreactors containing immobilized cells of proteus vulgaris ncim-2027. Biotechnol. Bioprocess. Eng. 16(4): 830-842.

Saratale R.G., Saratale G.D., Govindwar S.P., Kim D.S. (2015) Exploiting the efficacy of lysinibacillus sp. Rgs for decolourization and detoxification of industrial dyes, textile effluent and bioreactor studies. J. Environ. Sci. Health. A. Tox. Hazard. Subst. Environ. Eng. 50(2): 176-192. 
Skariyachan S., Prasanna A., Manjunath S.P., Karanth S.S., Nazre A. (2016) Environmental assessment of the degradation potential of mushroom fruit bodies of pleurotus ostreatus (jacq.: Fr.) p. Kumm. Towards synthetic azo dyes and contaminating effluents collected from textile industries in karnataka, india. Environ. Monit. Assess. 188(2): 121.

Srinivasan R., Karaoz U., Volegova M., MacKichan J., KatoMaeda M. (2015) Use of 16s rrna gene for identification of a broad range of clinically relevant bacterial pathogens. PLOS One. 10(2).

Telke A.A., Joshi S.M., Jadhav S.U., Tamboli D.P., Govindwar S.P. (2010) Decolourization and detoxification of congo red and textile industry effluent by an isolated bacterium pseudomonas sp. Su-ebt. Biodegradation 21(2): 283-296.

Vats A., Mishra S. (2017) Decolourization of complex dyes and textile effluent by extracellular enzymes of cyathus bulleri cultivated on agro-residues/domestic wastes and proposed pathway of degradation of kiton blue a and reactive orange 16. Environ. Sci. Pollut. Res. Int. 24(12): 11650-11662.
Wan J., Sun X., Liu C., Tang M., Li L., Ni H. (2017) Decolourization of textile dye rb19 using volcanic rock matrix immobilized bacillus thuringiensis cells with surface displayed laccase. World. J. Microbiol. Biotechnol. 33(6): 123.

Wang D., Zou J., Cai H., Huang Y., Li F., Cheng Q. (2018) Effective degradation of orange $g$ and rhodamine $b$ by alkali-activated hydrogen peroxide: Roles of $\mathrm{HO}_{2}$ and $\mathrm{O}_{2}$. Environ. Sci. Pollut. Res. Int. 26(2): 1445-1454.

Wong P.K., Yuen P.Y. (1996) Decolourization and biodegradation of methyl red by Klebsiella pneumoniae RS-13. Water Res. 30: 1736-1744.

Yuan X., Tian G., Zhao Y., Zhao L., Wang H., Ng T.B. (2016) Degradation of dyes using crude extract and a thermostable and ph-stable laccase isolated from pleurotus nebrodensis. Biosci. Rep. 36(4).

Zissi U., Lyberatos G., Pavlou S. (1997) Biodegradation of paminoazobenzene by Bacillus subtilis under aerobic conditions. J. Ind. Microbiol. Biotechnol. 19: 49-55. 